\title{
Introduction of Licensing Examination for the Registration of Medical and Dental Practitioners: Views of Stakeholders in Present Context of Bangladesh
}

\author{
Brig Gen (Dr) Md Abdullah Al Harun ${ }^{1}$, Brig Gen (Dr) Md Ahsan Habib ${ }^{2}$, Professor Dr Md Humayun Kabir Talukder ${ }^{3}$ \\ Dr. Md. Immam Hossin ${ }^{4}$, Dr. Md. Rasel Ahmad
}

\begin{abstract}
This cross sectional descriptive study was conducted among the health policy makers, health administrators, doctors including medical teachers, intern doctors, clinically exposed medical students and patients. The study was conducted at government and non government medical colleges of Dhaka and outside Dhaka from $1^{\text {st }}$ July 2014 to $30^{\text {th }}$ June 2015.

Total respondents were 372 and information was collected through in-depth interview schedule and self administered semi structured questionnaire. The qualitative information was collected from health policy makers including administrators by in-depth interview which was complimentary to the findings obtained by self administered semi structured questionnaire. Out of 372 respondents $280(75.3 \%)$ and $92(24.7 \%)$ were engaged in government and non- government hospitals/ organizations respectively.

Among the respondents 164 (44.1\%) agreed and 98 (26.3\%) strongly agreed that introduction of licensing examination for the medical and dental practitioners are justified in the present context of Bangladesh. Of the total, $294(79 \%)$ agreed and 40 $(10.8 \%)$ strongly agreed that licensing examination shall be useful for individual professional development and also agreed that this will help in overall professional development, shall improvement of professional competency and shall enrich doctors with updated professional knowledge.

Majority of the respondents (70.6\%) mentioned that doctors may not be interested. Of the same respondents $99.1 \%$ opined that the registration shall be on the basis of degree or the examination shall only be for person graduated from abroad or foreigner graduates. About $73 \%$ respondents were in agreement with 5 years validity period for an examination. Of the total $84.4 \%$ respondents agreed that the examination will improvement of standard of medical and dental education offered by all medical and dental colleges of Bangladesh.

There are many direct and indirect benefits of introducing licensing examination for the registration of medical and dental graduates/practitioners and there are a few barriers to implement that too.
\end{abstract}

Key Words: Licensing Examination, Registration of Practitioners, Views of Stakeholders.

\section{Introduction}

The need for medical or dental education is to produce medical and dental professionals with requisite knowledge, skills and professional attributes. The well planned medical education will be capable enough to produce medical and dental professionals with high level of understanding of the scientific and evidence based disciplines. Introduction of licensing examination for registration of medical \& dental practitioners will be the initiating and renewal steps which are

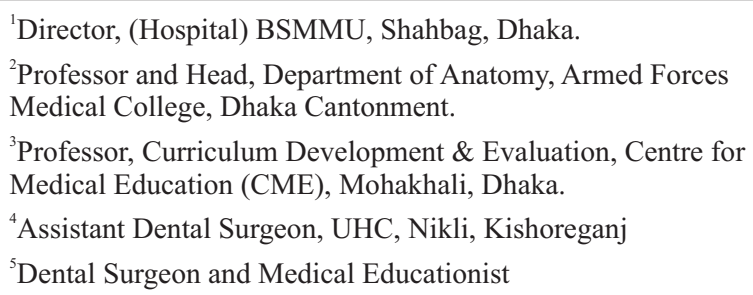

Address of correspondence: Brig Gen (Dr) Md Abdullah Al Harun Director (Hospital) BSMMU, Shahbag, Dhaka.

email: harun.bg.anc@gmail.com the recognition of their basic and subsequent professional development and training further.Medical education is ultimately aimed at continuously improving clinical practice and proper management of health problems. The speed of social changes demands skills and adopting our tools and resources to new situations and social needs. Thus medical and dental educations are practical and dynamic disciplines and those need constant review and research to become as well as to remain a useful tool to the society. After basic education and registration, doctors play a major role in the society and their work is subject to a range of internal work place pressures and external social pressures that influence their role, their target audience namely clients (patients) and advice on the basis of achieved knowledge and skills.

Medical education has to train future doctors in a way that they are capable of managing health problems of those who sick their services in competent and human manner. Today's medical and dental graduates not only need adequate knowledge, also the skill to use it. But this era of rapid advancement of it, may declare today's knowledge be obsolete

Bangladesh Journal of Medical Education 2017;8(1):2-8. C 2017 Harun et al., publisher and licensee Association for Medical Education. This is an Open Access article which permits unrestricted non-commercial use, provided the original work is properly cited. 
tomorrow ${ }^{1}$. Requirement of licensing examination for registration is likely to take place at that point. Therefore students and fresh medical and dental graduates must also be equipped with skills for self directed lifelong learning. Doctors need the competence to analyze and interpret clinical findings and translate them into a rational diagnostic and management plan. Additionally, professional practice should be aligned with the need of society. This change of focus from teaching to learning requires a whole new array of professional skills on the part of doctors ${ }^{1}$.

In medical and dental profession, the required education is basic medical education, postgraduate medical education and continuing medical education (CME) or lifelong learning. Basic medical and dental education is a foundation to be a responsible physician ${ }^{2,3}$. The basic undergraduate medical education is a 05 years for medical and 04 years for dental course with one year internship in each case. All programs culminate into Bachelor of Medicine and Bachelor of Surgery and Bachelor of Dental Surgery (BDS) degree respectively. Basic under graduate medical education which results in a graduate physician or a doctor in the society must have competence in science of medicine including practical skill and critical thinking, communication and ethics.

Bangladesh is a most densely populated lower middle incoming South East Asian country ${ }^{4}$. Per capita income in Bangladesh is US\$ 1314 which is 53 times less than the average US income ${ }^{5}$ and primary literacy rate is 60 percent. Bangladesh has about seventy thousand registered physicians ${ }^{6}$ and one physician for every 2586 persons ${ }^{7}$ which is bellow WHO minimum standard ${ }^{8}$. In Bangladesh there are 101 medical colleges, yearly about eight thousand medical and dental graduates are coming out from government, non government and Army medical colleges". Admission into basic medical and dental education is highly competitive in Bangladesh. Poverty, over population, lack of standard educational facilities and corruptions are major obstacles and are always embracing Bangladesh ${ }^{10,11}$.

The View of this topic is that the scare resources who are engaged directly and indirectly with health problems of Bangladesh as well as the globe should come to a standard which is parallel to the global one. South East Asian medical and dental council network (WHO, SEARO) has also opined for introducing licensing examination for the registration of medical and dental practitioners to assure their professional quality. Licensing for Registration is an official recognition of medical and dental practitioners stating that required or preset standards are achieved by the doctors and dental surgeons. Licensing examination can be compared with external quality control. Developed countries including many developing countries have their well known standards for registration of medical and dental practitioners since long time. Licensing examination for registration is required to warrant the presence of basic competence of knowledge, skill and professional attitude in medical and dental graduates while practicing. medical and dental practitioners will make medical and dental profession as well as graduates trustworthy not only to a community in the country but also to the whole world. This licensing examination and registration of medical and dental practitioners is the responsibility of Bangladesh medical and dental council (BMDC) and at present the authority is providing registration on the basis of paper documents like certificate awarded by the university, testimonials from the college and certain amount of fees only. Introduction of licensing examination for registration of medical and dental practitioners will be the initiating and renewal steps which are the recognition of their basic and subsequent professional development and training further.

Views of health policymakers, doctors, medical teachers, fresh graduates and clinically exposed medical and dental students regarding the present system and introduction of new system was a priority task for carrying out this study.

\section{Method}

This was a cross sectional descriptive type study conducted at Centre for Medical Education (CME) during the period July 2015 to Jun 2016. Total 372 participants were included. They were students, intern doctors, medical practitioners, dental practitioners, health policy makers, health administrators and patients. Sampling technique was purposive and convenient.

Inclusion criteria: Those who wish to participate in the study after initial briefing by researcher and volunteers were included.

Exclusion criteria: Those who could not complete the interview or were not willing to give opinion and the doctors graduated from foreign medical colleges.

Research instruments: One self administered semi structured questionnaire was used to collect information from medical and dental students, doctors, medical teachers and patients. In-depth interview schedule was prepared for health policy makers/administrators.

Data collection procedure: Data were collected from policy makers and health administrators by in-depth interviews. First of all director, Centre for Medical Education (CME) issued a letter for policy makers and health administrators, intern doctors, doctors, medical teachers, patients requesting to co-operate and collect data for thesis purpose. At the beginning of interview the researcher gave some introduction about the title of research. During interview pre-designed issues/questions were asked to policy maker/administrator. Opinions were written by the researcher as far as possible. With prior permission voice recorder was used to record data, who kindly allowed that. Data were collected from students, intern doctors, medical teachers, practitioners and patients by self administered semi structured questionnaire. Respondents were contacted in government and nongovernment medical college hospitals of Dhaka city (Dhaka

Introduction of licensing examination for the registration of

Bangladesh Journal of Medical Education 2017;8(1):2-8. 
Medical College, Sir Salimullah Medical College and Bangladesh medical college) and outside Dhaka (Pabna Medical College and North Bengal Medical College, Serajgonj). At the outset official permission was taken from working places of respondents. Researcher briefed the research subject to respondents and purpose of anonymous data for research and for development of medical and dental profession. Researcher requested the respondents to respond the statements in questionnaire. During response to questionnaire there were some quires from the respondents which were clarified by the researcher. Researcher thanked all participants after collection of filled up questionnaire from respondents, were checked and incomplete responses were completed immediately as far as possible.

\section{Results}

\section{General information}

To gather information regarding the need of introducing licensing examination for the medical and dental practitioners 20 policy makers $\&$ health administrators, 78 doctors, 103 intern doctors, 123 students and 68 patients were contacted. The mean age of the respondent was $27.42 \pm 7.715$. Of the total $62.9 \%$ were male. Out of 372 respondents $280(75.3 \%)$ were from government and 92 $(24.7 \%)$ were from private medical colleges. The academic qualifications of the respondents and nature of engagement are shown in table- 1 and 2 respectively.
Table 1: Distribution of the respondents by their academic qualification $(\mathrm{n}=372)$

\begin{tabular}{|l|c|c|}
\hline Academic qualification & Frequency & Percentage \\
\hline Under graduate & 91 & 24.46 \\
\hline MBBS & 201 & 54.03 \\
\hline BDS & 66 & 17.74 \\
\hline Post graduate & 04 & 1.07 \\
\hline Fellowship & 03 & 0.8 \\
\hline Others & 07 & 1.88 \\
\hline Total & 372 & 100.0 \\
\hline
\end{tabular}

Table 2: Distribution of the respondents by their category of engagement $(n=372)$.

\begin{tabular}{|l|c|c|}
\hline Nature of engagement & Frequency & Percentage \\
\hline Doctors & 78 & 21.0 \\
\hline Intern-doctors & 103 & 27.7 \\
\hline Patients & 68 & 18.3 \\
\hline Students & 123 & 33.1 \\
\hline Others & 07 & 1.88 \\
\hline Total & 372 & 100.0 \\
\hline
\end{tabular}

\section{Opinion on justification}

Out of the total respondents $164(44.1 \%)$ strongly agree that introduction of licensing examination for the registration of the medical and dental practitioners is justified and mean score and standard deviation of level of agreement were 3.77 and \pm 1.098 respectively (table -3 ) and uniform standard of medical/dental education was identified as best possible reason ( mean score $=4.02 \pm 0.425$ ).

Table- 3: Distribution of the respondents by their opinion on justification and possible reasons for introduction of licensing examination $(\mathrm{n}=372)$

\begin{tabular}{|c|c|c|c|c|c|c|}
\hline \multirow[t]{2}{*}{ Statement } & $\begin{array}{c}\text { SD } \\
1\end{array}$ & $\begin{array}{l}\mathbf{D} \\
\mathbf{2} \\
\end{array}$ & $\begin{array}{c}\text { NAND } \\
3\end{array}$ & $\begin{array}{l}\mathbf{A} \\
4\end{array}$ & $\begin{array}{c}\text { SA } \\
\mathbf{5}\end{array}$ & $\begin{array}{l}\text { Mean } \\
\pm \text { SD }\end{array}$ \\
\hline & f (\%) & $\mathbf{f}(\%)$ & $\mathbf{f}(\%)$ & f (\%) & $\mathbf{f}(\%)$ & \\
\hline $\begin{array}{l}\text { Licensing examination for the registration of the } \\
\text { medical and dental practitioners is justified }\end{array}$ & $\begin{array}{c}20 \\
(5.4) \\
\end{array}$ & $\begin{array}{c}33 \\
(8.9)\end{array}$ & $\begin{array}{c}57 \\
(15.3) \\
\end{array}$ & $\begin{array}{c}164 \\
(44.1) \\
\end{array}$ & $\begin{array}{c}98 \\
(26.3) \\
\end{array}$ & $\begin{array}{c}3.77 \\
\pm 1.098 \\
\end{array}$ \\
\hline \multicolumn{7}{|c|}{ Possible reasons for medical/dental practitioners licensing examination for registration } \\
\hline Uniform standard of medical/dental education & - & - & $\begin{array}{c}30 \\
(8.1)\end{array}$ & $\begin{array}{l}305 \\
(82)\end{array}$ & $\begin{array}{l}37 \\
(9.9)\end{array}$ & $\begin{array}{l}4.02 \pm \\
0.425\end{array}$ \\
\hline $\begin{array}{l}\text { Standard of individual medical/dental education } \\
\text { will be upgraded }\end{array}$ & - & $\begin{array}{c}1 \\
(0.3) \\
\end{array}$ & $\begin{array}{c}83 \\
(22.3) \\
\end{array}$ & $\begin{array}{c}277 \\
(74.5) \\
\end{array}$ & $\begin{array}{c}11 \\
(3.0)\end{array}$ & $\begin{array}{l}3.80 \pm \\
0.474\end{array}$ \\
\hline Legal advantage in practice & - & $\begin{array}{c}12 \\
(3.2)\end{array}$ & $\begin{array}{c}115 \\
(30.9)\end{array}$ & $\begin{array}{c}233 \\
(62.6)\end{array}$ & $\begin{array}{c}12 \\
(3.2)\end{array}$ & $\begin{array}{l}3.66 \pm \\
0.596\end{array}$ \\
\hline Embodiment of updated professional knowledge & - & $\begin{array}{c}15 \\
(4.0)\end{array}$ & $\begin{array}{c}79 \\
(21.2)\end{array}$ & $\begin{array}{c}275 \\
(73.9)\end{array}$ & $\begin{array}{c}003 \\
(0.8)\end{array}$ & $\begin{array}{c}3.72 \pm 0 \\
0.549\end{array}$ \\
\hline Public safeguard & $\begin{array}{c}28 \\
(7.5)\end{array}$ & & $\begin{array}{c}120 \\
(32.3)\end{array}$ & $\begin{array}{c}198 \\
(53.2)\end{array}$ & $\begin{array}{c}11 \\
(3.0)\end{array}$ & $\begin{array}{l}3.44 \pm \\
0.836\end{array}$ \\
\hline
\end{tabular}

Out of total respondents $90 \%$ agreed that introduction of licensing examination will help individual professional development (table-4). This shall improvement of professional competency of medical/dental practitioners (mean score $=3.88 \pm 0.516)$ and shall enrich doctors with updated professional knowledge (mean score $=3.81 \pm 0.456)$. 
Table 4: Distribution of the respondents by their opinions on benefits of introduction of licensing examination ( $\mathrm{n}=372$ )

\begin{tabular}{|c|c|c|c|c|c|c|}
\hline \multirow[t]{2}{*}{ Statement } & $\begin{array}{c}\text { SD } \\
1\end{array}$ & $\begin{array}{l}\mathbf{D} \\
\mathbf{2} \\
\end{array}$ & $\begin{array}{c}\text { NAND } \\
3\end{array}$ & $\begin{array}{c}\mathbf{A} \\
\mathbf{4} \\
\end{array}$ & $\begin{array}{c}\text { SA } \\
5\end{array}$ & $\begin{array}{l}\text { Mean } \\
\pm \text { SD }\end{array}$ \\
\hline & $f(\%)$ & $f(\%)$ & $f(\%)$ & f (\%) & $f(\%)$ & \\
\hline Individual professional development & $\begin{array}{c}05 \\
(1.3)\end{array}$ & $\begin{array}{c}01 \\
(.3)\end{array}$ & $\begin{array}{c}32 \\
(8.6)\end{array}$ & $\begin{array}{l}294 \\
(79)\end{array}$ & $\begin{array}{c}40 \\
(10.8)\end{array}$ & $\begin{array}{l}3.98 \pm \\
0.571\end{array}$ \\
\hline Overall professional development & - & - & $\begin{array}{c}49 \\
(13.2)\end{array}$ & $\begin{array}{c}298 \\
(80.1)\end{array}$ & $\begin{array}{c}25 \\
(6.7)\end{array}$ & $\begin{array}{l}3.94 \pm \\
0.442\end{array}$ \\
\hline $\begin{array}{l}\text { Improvement of professional competency of } \\
\text { medical/dentalpractitioners }\end{array}$ & - & - & $\begin{array}{c}74 \\
(19.9)\end{array}$ & $\begin{array}{l}268 \\
(72)\end{array}$ & $\begin{array}{c}30 \\
(8.1) \\
\end{array}$ & $\begin{array}{l}3.88 \pm \\
0.516 \\
\end{array}$ \\
\hline $\begin{array}{l}\text { Practitioners may be enriched with updated } \\
\text { professional knowledge }\end{array}$ & - & - & $\begin{array}{c}80 \\
(21.6)\end{array}$ & $\begin{array}{c}281 \\
(75.7)\end{array}$ & $\begin{array}{l}10 \\
(2.7)\end{array}$ & $\begin{array}{l}3.81 \pm \\
0.456\end{array}$ \\
\hline
\end{tabular}

Table 5: Distribution of respondents regarding the statement in relation to possible barriers of licensing examination $(\mathrm{n}=372)$

\begin{tabular}{|c|c|c|c|c|c|c|}
\hline \multirow[t]{2}{*}{ Statement } & $\begin{array}{c}\text { SD } \\
1\end{array}$ & $\begin{array}{l}\mathbf{D} \\
\mathbf{2}\end{array}$ & $\begin{array}{c}\text { NAND } \\
\mathbf{3}\end{array}$ & $\begin{array}{c}\mathbf{A} \\
\mathbf{4} \\
\end{array}$ & $\begin{array}{c}\text { SA } \\
5\end{array}$ & $\begin{array}{c}\text { Mean } \\
\pm \text { SD }\end{array}$ \\
\hline & $f(\%)$ & $f(\%)$ & $f(\%)$ & $f(\%)$ & $f(\%)$ & \\
\hline Doctors may not be interested & $\begin{array}{c}2 \\
(.5)\end{array}$ & $\begin{array}{c}6 \\
(1.6)\end{array}$ & $\begin{array}{c}82 \\
(22.3)\end{array}$ & $\begin{array}{c}259 \\
(70.6)\end{array}$ & $\begin{array}{c}18 \\
(4.9)\end{array}$ & $\begin{array}{c}3.78 \pm \\
0.581\end{array}$ \\
\hline Administrative problem & - & $\begin{array}{c}11 \\
(3.0)\end{array}$ & $\begin{array}{c}144 \\
(38.7)\end{array}$ & $\begin{array}{c}216 \\
(58.1)\end{array}$ & $\begin{array}{c}1 \\
(.3)\end{array}$ & $\begin{array}{c}3.56 \pm \\
0.559\end{array}$ \\
\hline Possibility of failure in examination & $\begin{array}{c}9 \\
(2.4)\end{array}$ & $\begin{array}{c}52 \\
(14)\end{array}$ & $\begin{array}{c}85 \\
(22.8)\end{array}$ & $\begin{array}{c}208 \\
(55.9)\end{array}$ & $\begin{array}{c}18 \\
(4.8)\end{array}$ & $\begin{array}{c}3.47 \pm \\
0.879\end{array}$ \\
\hline
\end{tabular}

Possibility of doctors not being interested for licensing examination was identified by $277(75.5 \%)$ of the respondent as barrier for the procedure (table-5). Administrative problem was identified as the second barrier (mean score $=3.56 \pm 0.559$ ) and $16.4 \%$ respondent disagreed that possibility of failure may be a barrier. Three percent of respondent was in favour of one examination with lifelong validity and table 6 presenting the tenure for fixed period proposed by the respondents. Of the total 317 respondents $209(65.9 \%)$ expressed that examination should be only for those who are graduated from abroad and 72 $(22.7 \%)$ expressed that license may be awarded on the basis of degree (Table-7). Of 341 respondents $48.7 \%$ preferred oral examination as the format of licensing examination (Table-8)

Table 6: Distribution of the respondents by their opinions about validity of licensing examination $(\mathrm{n}=357)$

\begin{tabular}{|l|c|c|}
\hline $\begin{array}{l}\text { Tenure for fixed time bound } \\
\text { validity of licensing }\end{array}$ & Frequency & Percentage \\
\hline 3 years & 69 & 19.3 \\
\hline 5 years & 262 & 73.4 \\
\hline 7 Years & 21 & 05.8 \\
\hline 10 years & 05 & 01.4 \\
\hline Total & 357 & 100.0 \\
\hline
\end{tabular}

Table 7: Distribution of the respondents by their opinions on the conditions of licensing examination for medical and dental practitioners $(\mathrm{n}=317)$

\begin{tabular}{|l|c|c|}
\hline $\begin{array}{l}\text { Conditions of licensing } \\
\text { examination }\end{array}$ & Frequency & Percentage \\
\hline $\begin{array}{l}\text { May be registered on the basis of } \\
\text { degree }\end{array}$ & 72 & $22.7 \%$ \\
\hline $\begin{array}{l}\text { Just after completion of internship } \\
\text { training }\end{array}$ & 03 & $0.9 \%$ \\
\hline Graduated from abroad & 209 & $65.9 \%$ \\
\hline Foreigner graduates & 33 & $10.4 \%$ \\
\hline Total & 317 & $100.0 \%$ \\
\hline
\end{tabular}

Table 8: Distribution of the respondents by their opinions on the format of licensing examination $(n=341)$

\begin{tabular}{|l|c|c|}
\hline $\begin{array}{l}\text { Different format of licensing } \\
\text { examination }\end{array}$ & Frequency & Percentage \\
\hline Oral examination & 166 & 48.7 \\
\hline Written examination & 75 & 22.0 \\
\hline Written and oral & 37 & 19.6 \\
\hline Others & 33 & 9.7 \\
\hline Total & 341 & 100.0 \\
\hline
\end{tabular}




\section{Suggestions}

Only 04 respondents gave suggestions which are:

1. Licensing examination should be objective oriented; so that the medical and dental practitioners may have a goal to improve upon their professional competencies.

2. Selection of examiner should be proper. They are to be selected who can give time for the purpose. They should be trained from abroad where medical licensing examination system is there.

3. Licensing examination may be conducted at list twice in a year and online submission including examination may be considered.

4. Organized seminar and symposium, workshop, congress should be there. So that senior doctors can attend in home and abroad to earn credits as it is there in many countries.

5. An alternative system can be found out in place of introducing licensing examination, like on the basis of tenure. Disciplinary ground may be considered.

6. After completion of intern-ship training a temporary license may be issued for 2 or 3 years to medical and dental practitioners.

\section{Discussion}

This cross sectional descriptive study was carried out among the health policy markers, health administrators, doctors including medical teachers, intern doctors, patients and clinically exposed medical students. The total participating respondents were 372. Majority (44.1\%) agreed and $26.3 \%$ expressed strongly agreement with the statement "Introduction of licensing examination for the registration of medical and dental practitioners is justified". In developed and many of developing countries in the world, doctors who desire to practice medicine legally need a license. The license provides a doctor the legal authority to undertake certain activities in the country, for example writing a prescription, signing a death certificate and holding some certain medical posts such as working in the health institutions ${ }^{12}$. Any doctor who wants to carryout professional activity for which a license is needed must be registered to practice. This applies whether the doctor is working full time or part time in the National Health Service or in the independent sector, self employed or working as a locum. Of the respondents of this study, $10.1 \%, 74.7 \%$ and $15.2 \%$ respectively neither agree nor disagree, agree and strongly agree that the examination is required for uniform standard of medical and dental education (mean score $=4.02 \pm 0.425$ ). Majority agreed that standard of individual medical and dental education will be upgraded (mean score $=4.8 \pm 0.474$ ), will update professional knowledge (mean score $=3.72 \pm$ 0.549 ) and will safeguard public (mean score $=3.44 \pm 0.836$ ).

All licensed doctors must demonstrate on an ongoing basis that they are up to date and feel to practice in chosen field and able to provide a good level of care. This means that the license to practice is no longer simply the recognition of doctor's qualification at point in time. It is becoming an indicator that the doctor continues to meet the professional standard set by General medical council (GMC) ${ }^{12}$ and specialist standards set by Royal medical colleges and faculties. Licensed doctors must provide evidence to demonstrate how they continue to meet those standards. The process of checking this evidence is to achieve revalidation or re-registration. Every licensed doctor must have appraisal periodically based on core guidance. As good medical practitioners they must collect supporting information about their practice so that they can discuss this with their appraiser and reflect on their practice. If a doctor does not engage with revalidation or renewal of registration, their license will be at risk. And authority concern may take steps to remove it ${ }^{12}$.

Licensing for registration of medical and dental practitioners are being practiced in deferent ways since long, around 100 years. Well known medical education quality assurance and quality control took place during the year of $1910^{13,14}$. Worldwide known and reliable professional regulatory bodies are general medical council (GMC); UK, Liaison committee on Medical Education (LCME); USA and Australian Medical Council (AMC). In Australia they are working for many years in their country and proved to be essential for medical education as well as good medical and dental professional practice ${ }^{15-18}$.

In this study, benefits of introduction of licensing examination of professional practitioners, majority respondents agreed or strongly agreed about individual professional development, overall professional development, improvement of competency of medical/dental practitioners and enriching with updated professional knowledge. Above all if there exists any basic shortage in medical education which produces medical and dental graduates get a chance to improve themselves through licensing examination for registration. Amen et $\mathrm{al}^{19}$ reported that there are challenges, opportunities and diversity in medical and dental profession in South Asia. Weak regulation, growth of medical colleges, in actual assessment process, admissions practice, stagnant curricula, antiquated emphasis on learning methods, inadequate clinical exposure specially in new medical colleges, shortage of qualified faculty, national corruption, historical sociopolitical structure, economic advancement are the studied challenges in questionable medical and dental practitioners in southeast Asia. There is also some dissimilarity in practice of registration system in these regional countries.

In this study respondents gave their views regarding possible barriers of introduction of licensing examination. Of total 372 respondents, $254(70.6 \%)$ agreed and $18(11.9 \%)$ strongly agreed that doctors may not be interested for appearing in licensing examination. It is interesting to note that as a condition, $65.9 \%$ respondents opined that the examination shall only be for those who are graduated from abroad and $22.7 \%$ \& $10.4 \%$ respectively opined that registration shall be on the basis of degree and that shall only be for foreign graduates. That is, $99.1 \%$ are not interested for appearing examination after intern-ship training. 
Recognition of medical graduate's out comes, in the Countries of Mexico and the Philippines medical graduates who took part in united states medical licensing examination (USMLE), result shows better performance of graduates from recognized medical schools. The medical graduates show better performance if educational standard is good. These results give guideline to introduce licensing examination for registration. Policy makers mentioned in their interview that many Bangladeshi medial graduates are doing odd jobs in abroad because they could not qualify the medical licensing examination in that county. If licensing examination is introduced in Bangladesh that will help medical graduates to qualify in aboard examination. Policy makers mentioned the theme; there would be many direct and indirect benefits of introducing licensing examination assuring quality of medical and dental practitioners in Bangladesh. The important is the population of Bangladesh will get better health services through modern invention, discovery in medical science will be incorporated at right time without delay. Patient safety will increase, complaints against doctors will decrease and less people will go abroad for treatment. This will decrease the expenses on health. Medical and dental graduate will get value, honor, and jobs in the world even in the developed countries. Through introduction of licensing examination medical graduates will be professionally proficient and will improve the health indicators of Bangladesh.

A number of young graduates think that national and individual cost of medical and dental graduates will increase with the achieving of global standard. Policy makers of this study did not give any opinion regarding increased cost if the licensing examination for registration is approved by global authority for recognition. Many developed and developing counties are having the frame work of licensing examination. In south Asia region out of 13 countries 9 are practicing licensing examination system. Very recently Nepal Medical Council (NMC) introduced written form MCQ based medical licensing examination for the registration of medical and dental practitioners.

Young graduates i.e. intern doctors extremely welcomed this licensing examination for registration. They also expressed medical students have the right to get quality education as because they will be medical graduates. They agreed that there are many benefits of introduction of licensing examination in building up their future career, there were very few positive opinions from clinically exposed medical students. WHO (2013) believes that benefits of recognition of medical and dental practitioner self evident as seen by long time use of rigorous improvement of undergraduate medical education in USA and $\mathrm{UK}^{20}$.

\section{Conclusion}

The issue introduction of licensing examination for the medical and dental practitioners' has been extremely welcomed by the respondents less clinically exposed medical students as there is a question of examination. In Bangladesh presently there are around 101 medical and 32 dental colleges and more or less 8000 medical and dental graduates are coming out every year. Among those some are doing well but many are having explicit weakness. But there is no organized system of quality control or professional development for those doctors who are practicing the profession starting after being graduated from medical and dental colleges. Now it has been realized that after being graduated from medical and dental colleges there should be a system of registration thorough an organized examination for licensing for holistic development of medical and dental professional practice in Bangladesh. It is well known that ultimate aim of medical and dental professional practice is to ensure patient safety and health for all. This study figured out that this is an age of globalization. Recognition of our medical and dental practitioners and their professionalism will be very much required in coming future. There are many direct and indirect benefits of introducing licensing examination for the registration of medical and dental graduates/practitioners and there are a few barriers to implement that too. Only strong commitment, goodwill and coordinated efforts can establish the system of licensing examination in Bangladesh.

Now it is the time to make, short term and long term futuristic plan for achieving global standard of medical and dental practitioners in Bangladesh without delay to make competent medical and dental graduates to provide better health services.

\section{References}

1. Amin Z,Burdick W P, Avinash S and Sing (2010). Relevance of the Flexner Report to contemporary Medical Education in South East Asia. Academic Medicine;85(2):333-9.

2. Karle H, Walton H, Lindgren S (2012). The World Federation of Medical Education. History of First Forty Years 1972-2012. World Federation of Medical Education: Copenhagen. http//www.wfme.org; visited on12-12-2016.

3. World Federation on Medical Education, WFME (2012). http://www.wfme.org; visited on 06-02-2016.

4. Wikipedia (2013).Demographics Bangladesh.en. wikipedia.org/wiki/physician visited on 23-8-2015.

5. Prothom Alo (2015). Way to middle income country; The daily Prothom Alo; Dhaka, Bangladesh. Dated $1^{\text {st }}$ Jan 2015. Prothom Alo.com.

6. BM\&DC (2014). Registered Doctors' Detals. Bangladesh Medical and Dental Council; Dhaka. www.dhakatribune.com/bangladesh/registereddoctors; visited 01-2-2016.

7. DGHS (2014). Health Bulletin. Management Information system; Directorate General of Health Services. Mohakhali: Dhaka 1212 www.dghs.gov; visited 04-01-2016

8. Huq M (2014). Transforming Medical Education towards Universal Health Coverage : What should be the strategy in Bangladesh ? National seminar on Health 
professionals Education in Bangladesh. Association for Medical Education: Dhaka, p24-25.

9. Islam MS (2015). Again New Medical College? The Daily Prothom Alo: Dhaka Dated $1^{\text {st }}$ January.

10. Amin Z,Merrlees N, Hanif A, Talukder M H K (2008). Medical education in Bangladesh. Medical teacher; 30: 243-7.

11. TIB (2008). Transparency International Bangladesh. Corruption perceptions index. A vailable at; http;//www.transperency.org/news room/in focus/; visited on 12-10-2015.

12. GMC (1993). Tomorrows' Doctors. Recommendation on undergraduate Medical Education. The Education committee of General Medical Council: London GMC 2009. Tomorrow's Doctors. General Medical Council: UK.www.gmcuk; visited on 05-20-2016

13. Flexner A (1910). Medical education in the United states and Canada, A report to the Carnegie Foundation for the advancement of Teaching. Carnegie Foundation: New York. Bulletin no 4.

14. Islam AFMS (2014). Introductory notes on theorizing perspective issues in Accreditation and Quality health professionals Education in Bangladesh. Key note speech on National Seminar on Health professionals Education in Bangladesh. MMEd Thesis (CME). Dhaka: Bangladesh.
15. GMC (2009). Tomorrow's doctor. General Medical Council :UK. www.gmcuk; visited on 6-3-2016.

16. LCME (2008). LCME Accreditation Guideline for New and developing Medical School. Liaison Committee on Medical Education. Association of American Medical Colleges: Washington DC.www.lcme.org; visited on 12-11-2015.

17. LCME (2014). Function and structure of Medical School, Standards for Accreditation of Medical Education Program leading to M.D Degree. http://www.lcme.org; visited on 12-12-2016.

18 AMC (2002). Assessments and Accreditation of Medical schools. Standards and Procedures of Medical school. Australian Medical Council. www.amc.org; visited on 03-3-2016.

19. Amin Z, Burdick WP, Avinash S, Sing T (2010). Relevance of the Flexner Report to Contemporary Medical Education in south Asia. Academic Medicine; 85(2):333-9.

20. WHO (2013).Transforming and scaling up Health professionals Education and Training policy Brief on Accreditation of institutions for Health professionals. World Health Organization, Geneva, www.who.int, ISBN 9789241506359; visited on 04-01-2016. 